Anna Austestad og Eva Lutnces

Tilnærminger til teknologi og design i grunnskolen

- Nysgjerrig, skapende, kritisk?

\begin{abstract}
Sammendrag
Hva skal elevene lare i emnet Teknologi og design $(T \& D)$ i grunnskolen? Hvorfor skal elever lare $T \& D$ ? I denne artikkelen unders $\phi k e r$ vi hvilke didaktiske begrunnelser for T\&D som gir seg til kjenne i undervisningsmateriell hentet fra sentrale aktører innen T\&D. Det skisseres fire ulike tilnarminger $i$ aksen mellom design og teknologi som svar på disse spфrsmålene. Det argumenteres for at den teknologi- og designforståelse som ligger til grunn for undervisningspraksis får konsekvenser for hvordan emneområdet begrunnes, operasjonaliseres og hvilken kompetanse elevene sitter igjen med etter opplaringen.
\end{abstract}

Nøkkelord: Teknologi og design, designdidaktikk, grunnskolen, Kunnskapsløftet.

\title{
Innledning
}

Høsten 2006 ble Teknologi og design (T\&D) etablert som et flerfaglig emne i den nye æreplanen for grunnskolen - Kunnskapsl $\phi f t e t$ (Kunnskapsdepartementet 2006). I den fagpolitiske prosessen som førte frem til emneområdets tilblivelse ser vi ulike didaktiske begrunnelser for T\&D. Så hvordan begrunnes emneområdet T\&D etter implementeringen av Kunnskapsløftet, finner vi igjen de begrunnelsene som ble brukt for at emneområdet ble innført? I denne artikkelen undersøker vi undervisningsmateriell som er utarbeidet av sentrale aktører innen T\&D, med spørsmål om hvilke didaktiske begrunnelser som har fått gjennomslag og feste i praksis. Teknologirådet var en sentral aktør i prosessen mot å etablere T\&D i Kunnskaps løftet, og utarbeidet en visjon for fagområdet:

Norsk ungdom vokser opp i et høyteknologisk samfunn, men teknologi er lite synlig på timeplanen. Skolen bør gi elevene forståelse av og erfaring med utvikling av teknologi, for å vise at teknologiske produkter og systemer skapes av mennesker som foretar bevisste valg i gitte sammenhenger. Dette kan stimulere elevene til å opptre nysgjerrig, skapende og kritisk i forhold til teknologi. (Teknologirådet 2004:1, vår kursivering )

Teknologirådet argumenterer for at elever gjennom forståelse av og erfaring med teknologi kan møte den teknologiske hverdag som nysgjerrige, skapende og kritiske. Teknologirådets begrunnelse for emneområdet tar utgangspunkt $\mathrm{i}$ den virkelighet dagens ungdom befinner seg $\mathrm{i}$, et samfunn der teknologi bidrar til å forbedre og forme våre eksistensvilkår. Ved å få erfaring med hvordan utviklingsprosesser tar utgangspunkt i ideer, behov, kontekst, kultur, materialvalg, produksjon, testing, presentasjon og evaluering, kan elever få forståelse for hvordan produkter og systemer blir til, skapt av mennesker som foretar bevisste valg i gitte sammenhenger (ibid, s. 2). Den praktiske tilnærmingen kan gi elevene eierforhold til T\&D, noe som kan senke terskelen for aktivt å forholde seg til sine omgivelser og gi rom for deltagelse i den offentlige debatt (ibid). Samtidig oppfordrer Teknologirådet til at elevene løfter blikket fra sin egen produktutvikling for å diskutere og reflektere over samfunnsmessige utfordringer ved teknologi. På denne måten skisseres en didaktisk begrunnelse for fagområdets plass i skoleverket. Det å se sammenhengen mellom teknologi, menneske, samfunn og natur (ibid:3), anses som like viktig som produktutvikling - for å kunne møte samtiden og fremtidens utfordringer.

En annen didaktisk begrunnelse finnes $\mathrm{i}$ den politiske prosessen som fører frem til T\&D blir del av Kunnskapsløftet. Emneområde i grunnskolen startet som prosjektet Teknologi i Skolen i 1996, på initiativ fra Norges Ingeniørorganisasjon. Målet var å etablere 
teknologi i den norske skolehverdagen (NITO 2008). Timingen for å starte arbeidet mot å gjøre teknologi til en del av timeplanen kunne ikke vært bedre. Rekrutteringen til yrker innen teknologi og realfag var synkende, og internasjonale tester som TIMSS og PISA viser svake resultater for norske elever i realfag (Utdannings- og forskningsdepartementet 2002:18). Det så en stund ut til at Teknologi blir et nytt fag i grunnskolen, den 5. juni 2003 foreslo Kvalitetsutvalget at: "Teknologi og design opprettes som et fag på ungdomstrinnet" (Utdannings- og forskningsdepartementet 2003:21). Kvalitetsutvalget legger til begrepet design i fagbetegnelsen, men begrunnelsen for å opprette et nytt fag forblir den samme; det er realfagene som skal styrkes (ibid:148,188). I St.meld 30, Kultur for laring, foreslås det at T\&D legges inn under de ordinære fagene, i stedet for å etableres som et eget fag (Utdannings- og forskningsdepartementet 2004). I dokumentene som ledet frem mot at T\&D ble etablert i Kunnskapsløftet (Kunnskapsdepartementet 2006), understrekes kombinasjonen av erfaring og forståelse som innfallsport til arbeid med T\&D. Når Kunnskapsløftet spres til lærerværelser over hele landet, er T\&D blitt et: "flerfaglig emne der naturfag, matematikk og kunst og håndverk samarbeider" (ibid:83). ${ }^{1}$ Matematikk skal vise: "sin nytte som reiskapsfag" (ibid:57) og faget Kunst og håndverk skal bidra med: "det praktisk-estetiske aspek tet ved design” (ibid:129). I læreplanen for Naturfag skisseres T\&D som et eget hovedområde, der det flerfaglige emnet beskrives slik: "Teknologi og design dreier seg om å planlegge, utvikle og fremstille produkter til nytte i hverdagen" (ibid:83). Begreper som redskapsfag, praktiskestetisk og fremstille understreker at den praktiske tilnærmingen til T\&D har fått en fremtredende plass i Kunnskapsløftet og viser tråden fra Teknologirådet. Praktiske tilnærminger blir et grunnprinsipp for arbeid med T\&D. "Prinsippet er: lære ved å gjøre" skriver Pål Kirkeby Hansen og Svein Briså (2004:?) i artikkelen Teknologi som nytt fag $i$ skolen. Innebygd i dette ligger en kritikk av tradisjonell naturfags- og matematikkundervisning. Kunnskaper og prinsipper skal anvendes, ikke bare forstås (ibid).

I dette risset over fremveksten av $\mathrm{T} \& \mathrm{D}$, vises ulike didaktiske begrunnelser for emnet $\mathrm{i}$ skolen. Mens Teknologirådet plasserer teknologi mellom produktutvikling og samfunnsmessige perspektiver, ser den politiske diskusjonen T\&D i større grad som et redskap for å løfte realfagene, og gjøre en teoretisk timeplan mer praktisk. Hva kan dette komme av? Berit Bungum påpeker at: "det fins svært ulike ideer om hva teknologi som kunnskapsområde innbefatter, og følgelig hva teknologi som fagområde i skolen skal inneholde og hva slags kompetanse det sikter mot for elevene" (2006:29). Dette antyder at kunnskapsområdet teknologi ikke er entydig, men kan gis ulikt innhold ut i fra bla. formål og den sammenheng det fremtrer i, noe som begrunner hvorfor fagområdet teknologi kan bli gitt ulike didaktiske begrunnelser og kan tilnærmes på ulike måter. Inspirert av Fensham og Gardner (1994), beskriver Bungum (2006:29) fire ulike tilnærminger til teknologiundervisning:

- Teknologi som anvendt naturvitenskap; der teknologiske eksempler illustrerer anvendelser av naturvitenskapelig kunnskap.

- Teknologi som utgangspunkt for innsikt i naturvitenskap; der teknologiske problemstillinger vil definere hvilke naturvitenskapelige kunnskaper som vektlegges.

- Teknologi og naturvitenskap som uavhengige fag; der feltenes egenart understrekes.

- Partnerskap mellom naturvitenskap og teknologi; der naturvitenskap og teknologi er likestilte virksomheter og avhengig av hverandre.

Mens Bungum viser til relasjoner mellom teknologi og naturvitenskap, finner vi ingen lignende undersøkelse av akser mellom teknologi og design, som ble navnet på det flerfaglige emnet. På samme måte som Bungum ser på teknologi som et flerfoldig kunnskapsområde med mange tilnærmingsmåter, vil vi analysere kunnskapsområdene design og teknologi, slik de fremkommer i undervisningsmateriell hentet fra sentrale aktører innen T\&D: Renate- 
senteret, Teknologi- \& designboka, Naturfagssenteret og Norsk Form. Videre vil vi se nærmere på hvordan kunnskapsområdene forholder seg til hverandre. I analysen begrenser vi oss til å bygge videre på Bungums fire kategorier og begrepsbruk. Er det Teknologirådets visjon om den nysgjerrige, skapende og kritiske elev som er fremtredende? Eller er det andre tilnærminger til design og teknologi som gjør seg gjeldende? Hva angir undervisningsmateriellet som sentralt lærestoff? Hvilke didaktiske begrunnelser for T\&D kan ligge til grunn?

\section{Renatesenteret ${ }^{2}$ : Design som utgangspunkt for å forstå teknologi}

Teknologi og design. Hefte for barneskolen (Renatesenteret 2005), ble sendt ut til alle barneskoler i Norge, ved oppstart av Kunnskapsløftet høsten 2006. For mange lærere var heftet deres første møte med det flerfaglige emnet T\&D. Heftet, på 16 sider, gir en introduksjon til hvorfor T\&D har blitt en del av norsk skole, hva T\&D er, og tre eksempler på T\&D-aktiviteter for barnetrinnet. Renatesenteret introduserer leseren til design gjennom fork laringen på hvorfor teknologi står foran design i T\&D: "Design er et redskap og metode i arbeidet med å forstå og tilegne seg kunnskaper om og ferdigheter i teknologi"(ibid:6). Renatesenteret viser til hvordan fagområdene design og teknologi møtes gjennom produktutvikling. Samtidig, og med henvisning til Stortingets vedtak, juni 2004 (ibid:3), påpekes det at design er underordnet teknologi $\mathrm{i}$ T\&D. Det er vanskelig å se reduseringen av design til å være et redskap for å forstå teknologi som en konstruktiv invitasjon til et flerfaglig samarbeid med kunst- og håndverkslærere. I fagplanen for Kunst og håndverk er 22 kompetansemål tilknyttet hovedområdet design (Kunnskapsdepartementet 2006:132-135). I den forstand kan Anne Stol Øyan (2004:87) ha rett når hun hevder at designbegrepet bare har blitt et "in-begrep" som skal sørge for å gi realfagene et positivt løft. Kanskje har ikke Renatesenteret tatt innover seg Kunnskapsløftets etablering av emneområdet som flerfaglig?

Teknologi er ikke som design viet en selvstendig begrepsavklaring i Renatesenterets hefte, men leseren introduseres til flere didaktiske begrunnelser. Teknologi presenteres som et selvstendig fagområde med stor betydning for menneskenes hverdag. Med henvisning til "Generell del" i læreplanen argumenteres det for teknologiundervisningens allmenndannende verdi (Renatesenteret 2005:2). En annen tilnærming er T\&D som middel til å styrke realfagenes stilling i samfunnet og deres praktiske innretning (ibid:3). I tillegg kommer den nevnte tilnærmingen teknologi som produktutvikling, der teknologi sees i sammenheng med design (ibid:6). Design begrenses til verktøyet som skal sørge for den praktiske tilnærmingen til kunnskaper i teknologi, et middel for å nå det egentlige målet; innsikt i teknologi. Den didaktiske begrunnelsen for design $\mathrm{i}$ heftet handler om å legge til rette for elevenes teknologiforståelse.

\section{Teknologi og designboka: T\&D som anvendt naturvitenskap gjennom praktisk arbeid}

Teknologi- og designboka (Briså, Ingebrigtsen og Jørgensen 2006), som er rettet mot læreren, presenterer seg på bokens bakside som en praktisk prosjektbok med detaljerte oppskrifter på produkter elevene kan bygge i klasserommet. Vi har valgt "Mekanisk leke" (ibid:128-137) som eksempel. Med overskrifter som "dette trenger du", "slik gjør du" og "slik virker det" ledes elevene gjennom oppgaven. Dersom elevene følger oppskriften nøye nok, vil de erfare hvordan bevegelse forflytter seg gjennom leken; en sirkelbevegelse overføres til en opp- og nedbevegelse og høna beveger seg. Fremgangsmåten minner om fors $\varnothing \mathrm{k}$ i tradisjonell naturfagsundervisning, der elevene gjentar velprøvde oppskrifter, for å se naturvitenskapelige prinsipper med egne фyne. ${ }^{3}$ Det ligger en fasit forut for elevenes produksjon. Teknologi- og designboka gir ikke til kjenne noen eksplisitt forståelse av design, men kan knyttes til det praktiske aspektet, nemlig det å gjøre noe med hendene. Teknologi- og designboka knytter følgende kompetansemål fra læreplanen i naturfag til prosjektet: "Planlegge, bygge og teste 
mekaniske leker, beskrive ulike bevegelser i lekene og prinsipper for mekaniske overføringer" (ibid:128). Slik "Mekanisk leke" er beskrevet i Teknologi- og designboka er det bare "kunne bygge" som dekkes. Faren er overhengende for at elevene ved å følge oppskriften forblir i en ureflektert gjøren, der det å diskutere prinsipper for mekaniske overføringer oppleves som ekstraarbeid, snarere enn en integrert del av oppgaven. Det overlates til lærens didaktiske kompetanse å sørge for at de andre elementene i kompetansemålet realiseres.

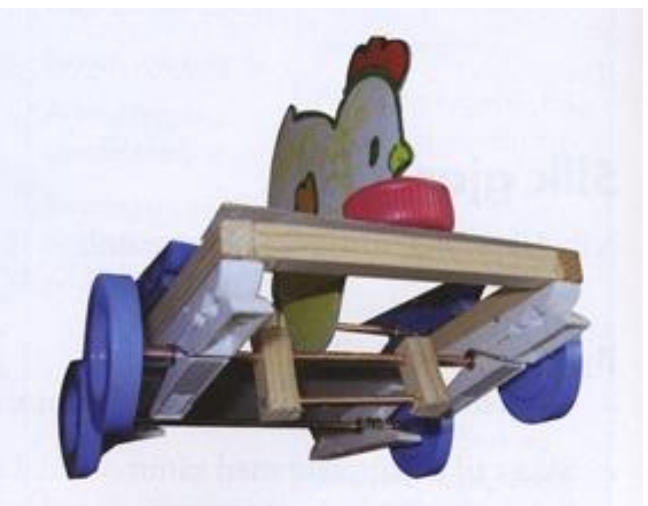

Figur 1 Teknologi-og designboka: Mekanisk leke

Det er ingen kritisk refleksjon i "Forord" eller "Innledning" i forhold til hva slags læring elevene sitter igjen med etter å ha fulgt en oppskrift, men i innledningen oppfordres det til at elevene skal lage sin egen variant av gjenstanden for at det skal bli et T\&D-prosjekt (ibid:9). Hvor stor variasjonen fra oppskriften bør være gis læreren ingen retningslinjer for. I "Mekanisk leke" legges det opp til at elevene kan bytte ut høna med en valgfri figur, men oppgaven forblir ellers den samme (ibid:130). Er dette nok til å løfte oppgaven fra å være en oppskrift til å bli et T\&D-prosjekt? Når elevene blir bedt om å variere oppskriften på formplanet, deltar de i en utviklingsprosess. Her kan det også ligge en implisitt forståelse av design.

I oppgaven er både problemet og løsningen gitt på forhånd - eleven er satt til å reprodusere, og endre litt på en allerede kjent oppskrift. Den didaktiske begrunnelsen for T\&D i "Mekanisk leke" blir å se bevegelsesmekanikk i praksis, med andre ord anvendt naturvitenskap. Design blir oppfattet som det å variere en oppskrift og det praktiske aspektet ved det å lage et produkt.

\section{Naturfagssenteret: Design og teknologi i uavhengige prosesser}

Neste eksempel er "Elektronisk jakkemerke", en læringsressurs fra nettstedet naturfag.no (Paulsen 2008), utvik let av Nasjonalt senter for naturfag i opplæringen (Naturfagsenteret). Det elektroniske jakkemerket lages av mosegummi og lysdioder. Fremgangsmåten er beskrevet trinnvis, sammen med en utstyrsliste og relevante kompetansemål. Elevenes praktiske arbeid er delt $\mathrm{i}$ to prosesser, en for form og en for elektronikk. Først skal elevene gjennom "Del 1: design og produksjon av ansiktet/hodet". Det som beskrives som designprosessen er knyttet til utseende på jakkemerket, hvor elevene oppfordres til å finne en passende form/figur for sitt jakkemerke. "Del 2 Lag et 'printkort' med en enkel strømkrets", beskriver hvordan ele vene skal lodde sammen lysdioder, kobbertape og batteri. Oppgaven formidler design og teknologi som uavhengige fagområder, der design og teknologi sees som atskilte aspekter ved utviklingen av et produkt. Design brukes i oppgaven synonymt med utseendet på jakkemerket, og teknologi synonymt med elektronikken på baksiden. Ved å skille fagområdene tas det ikke 
høyde for hvordan teknologiske og funksjonelle egenskaper ved et produkt betinger - og betinges - av formen. Hvilken fagkompetanse formidler "Elektronisk jakkemerke'? Ved å lage sitt eget printkort făr elevene erfaring med hvordan en strømkrets fungerer, teknologi er knyttet til anvendelsen av elektronikk. Design er knyttet til dekorering av og utseende på jakkemerket, hvordan elevene kan bruke form og farge. Den didaktiske begrunnelsen for produktutviklingen handler om å få erfaring med naturvitenskapelige prinsipper for elektronikk og gi en figur form. Elektronikken blir viktig for naturvitenskapens skyld, formen blir viktig for formens skyld.

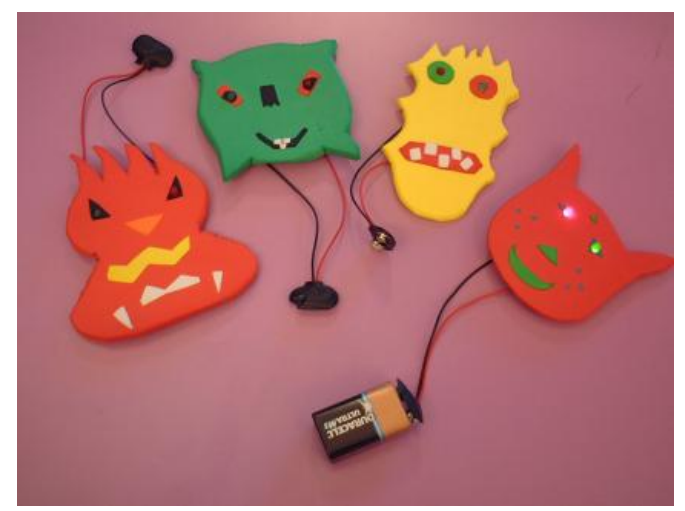

Figur 2 naturfag.no: Elektronisk jakkemerke

\section{Norsk Form: Design og teknologi i partne rskap}

Som siste aktør vender vi oss mot Norsk Form (2005) for å se hva slags forståelse av design og teknologi som fremtrer i "Mobiltelefonholder". Undervisningsopplegget er laget i samarbeid mellom Norsk Form og Renatesenteret, som et pilotprosjekt ved Trosvik skole høsten 2005. I prosjektet skal elevene gjennom en designprosess erfare produktutvikling. I foreldreog elevveiledningen begrunnes denne oppgaven med at mange mennesker i dag har mobiltelefoner, som skaper nye behov. Elevene får i oppgave å avgjøre hvem som skal være brukeren av mobiltelefonholderen og hvor plasseringen av den skal være. Dette prosjektet vektlegger designprosessen og skisserer et mer åpent forløp enn et det vi har beskrevet i de tre første eksemplene på undervisningsmateriell. I introduksjonen til prosjektet fremholdes det at design ikke har noen fasit. Prosjektet er preget av en større sammentenkning mellom bruk og form, og leder elevene gjennom en trinnvis designprosess, hvor søking etter fakta, problem, ide, losning og aksept er milepæler i prosessen. Elevenes selvstendige arbeid står sentralt $\mathrm{i}$ hele prosessen, fra å hente inn visuelle referanser, undersøkelse av behov hos relevant bruker, utforming av problemstilling og modellering av arbeidsmodell. Alt arbeidet i designprosessen skal dokumenteres i en mappe.

Ved første Øyenkast synes teknologi nedtonet i oppgaven. Er det slik at dersom designprosessen gis større vekt, forsvinner det teknologiske aspektet? Eller er det en annen forståelse av teknologi som fremtrer i undervisningsopplegget? Kunnskapsløftets formulering om at: "Teknologi og design dreier seg om å planlegge, utvikle og framstille produkter til nytte i hverdagen" (Kunnskapsdepartementet 2006:83) synes å være toneangivende, og oppgaven viser således en annen tilnærming til T\&D. Eksemplet "Mobiltelefonholder" tar utgangspunkt i en vid forståelse av teknologi, mer i tråd med Generell del i Kunnskapsløftet: "Teknologi er framgangsmåter menneskene har utviklet for å nå sine mål, arbeide lettere og samarbeide bedre" (ibid:9). Samtidig er denne tilnærmingen til teknologi parallell til Herbert Simons brede definisjon av design: "Everyone designs who devises courses of action aimed at changing existing situations into preferred ones" (1969:54). 


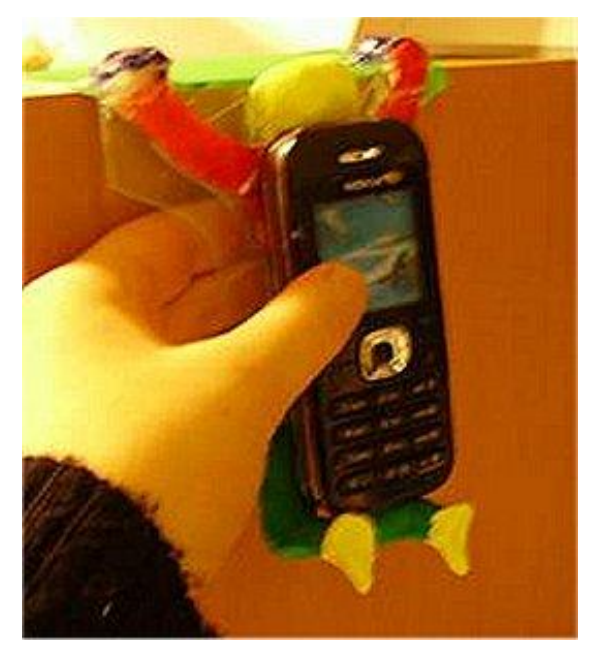

Figur 3 Norsk Form: Mobiltelefonholder

Elevene bes om å ta stilling til hvem som kan ha behov for en mobiltelefonholder, leve seg inn $\mathrm{i}$ brukerens behov og utforme en problemstilling som utgangspunkt for videre formgivning av mobiltelefonen (Norsk Form 2005).Her blir design og teknologi to felt som møtes, og som går utover å anvende naturvitenskapelige prinsipper i praksis. Samtidig kan realfagene ivaretas og synliggjøres ved at en for eksempel reflekterer over hvilke naturvitenskapelige prinsipper som er i operasjon og som nyttiggjøres i hvert enkelt produkt. Det gir rom for undervisning som understreker et samspill, hvor elevene får forståelse med hvordan utviklingen av et produkt fore går ved å ta valg knyttet til bruker, form og funksjon.

\section{Oppsumme ring: Fire tilnærmingsmå ter til T\&D i undervisnings materiell}

Fellesnevneren for T\&D i undervisningsmateriellet vi har analysert er at elevene skal lage et eget produkt. Her skiller likevel undervisningsmateriellet lag, og differensieres gjennom deres tilnærming til design og teknologi. I de fire eksemplene på undervisnings materiell har vi sett følgende tilnærmingsmåter til emneområdet T\&D:

- Design som verktфy for å forstå teknologi.

I Renatesenterets (2005) Teknologi og design. Hefte for barneskolen posisjoneres design som et praktisk redskap for å forstå teknologi. Teknologi har potensial for allmenndanning og styrking av realfagene.

- $\quad$ T\&D som anvendt naturvitenskap gjennom praktisk arbeid.

I "Mekanisk leke" fra Teknologi- og designboka (Briså, Ingebrigtsen og Jørgensen 2006:128-137) er hovedbegrunnelsen for T\&D å se naturvitenskap i praksis. Design blir oppfattet som det å variere en oppskrift - og som det praktiske aspek tet ved det å lage et produkt.

- Design og teknologi i uavhengige prosesser.

I "Elektronisk jakkemerke" (Paulsen 2008) fra Naturfagsenterets nettsted naturfag.no sees design og teknologi som uavhengige fagområder ved utvik lingen av et produkt. Teknologi er knyttet til elektronikken og design er knyttet til dekor og utseende.

- $\quad T \& D$ i partnerskap.

En fjerde tilnærming viser hvordan design og teknologi går i partnerskap, der felles fokus er gjenstander til bruk og forbedring av hverdagen. Design og teknologi handler om en prosess hvor identifisering av et problem knyttet til brukernes behov, funksjonalitet og formale formgivning står sentralt. 
Vi vender tilbake til spørsmålet $\mathrm{i}$ innledningen om hvilken kompetanse $\mathrm{i}$ emnet som ansees som sentral - hva skal elevene lære gjennom T\&D? Dersom den didaktiske begrunnelsen for T\&D er å styrke realfagene ved å gi elevene praktisk erfaring med naturvitenskapelige prinsipper, synes de tre første tilnærmingene hensiktsmessige. Løsningen foreligger i stor grad i forkant av elevenes produktutvikling, i tråd med Renatesenterets forståelse: "utfallet av utviklingsprosessen er til en stor grad bestemt på forhånd, og gjerne ikke av utvikleren selv (2005:6). I de tre første tilnærmingene gjennomføres elevenes praktiske virke i spennet gjennom å reprodusere en oppskrift og variere den samme oppskriften. Elevens produktutvikling, eller designprosess, er knyttet til variasjon av formen, og ikke den teknologiske løsningen og produktet som helhet. Realfagenes nytteverdi synliggjøres for elevene og/eller elevene tilbys en alternativ vei til realfagskunnskap. Design blir et redskap for å forstå teknologi - som igjen er et redskap for å forstå realfag. I disse tilnærmingene blir formålet med T\&D i hovedsak å få erfaring med realfag i praksis, og både teknologi og design blir midler til å nå det egentlige målet: realfag. I den siste tilnærmingen derimot blir design og teknologi komplementære, iden forstand at begge knyttes opp mot det å skape gjenstander til nytte og forbedring av hverdagen. Når fagområdet blir sett på som et partnerskap mellom teknologi og design, gir det en annen innfallsvinkel til undervisning i emnet. I partnerskapet ligger kimen til at T\&D kan bli et selvstendig område, som gir et selvstendig blikk rettet mot den materielle og teknologiske sfæren av vårt dagligliv. Dermed blir ikke $T \& D$ et verktøy for realfag alene, men et mål i seg selv - et felt med egenverdi. Der hovedbegrunnelsen for T\&D begrenser seg til å se naturvitenskapelige prinsipper i praksis, blir elevenes selvstendige produktutvikling overflødig - de vil nå målet like bra om de følger en oppskrift. Design blir forstått i snever forstand som formgivingen av utseende på et produkt og variasjon av etablerte oppskrifter. Design er løsrevet fra en sammenheng: funksjon, bruker og tekniske egenskaper ved produktet. Der teknologi og design sees i partnerskap blir design forstått vidt: som produktutvikling i sammenheng mellom form og funksjon, ikke kun knyttet til utseende. Vår analyse synliggjør to ulike didaktiske begrunnelser for emneområdet i undervisningsmateriellet. Den ene ser T\&D som et middel for å lære realfag, den andre ser T\&D som et mål i seg selv.

\section{Nysgjerrig, skapende, kritisk?}

I artikkelen har vi sett at undervisningsmateriell i T\&D kan gi rom for at elever kan få erfaring og forståelse av realfag i praksis og å utvikle produkter. Dette støtter føringene fra Kunnskapsløftet, hvor fokus ligger på å planlegge, utvikle og fremstille produkter til nytte i hverdagen, ved å ta utgangspunkt i naturfaglige prinsipper for å forstå teknologisk virksomhet (Kunnskapsdepartementet 2006:83).

Går vi tilbake til Teknologirådets argumentasjon for å etablere T\&D i skoleverket, handlet denne om mer enn en alternativ vei til realfagskunnskap og å fremstille produkter til nytte i hverdagen. I visjonen fra Teknologirådet var målet at elever i faget Teknologi skulle få erfaring med, og forståelse for, hvordan teknologi blir til gjennom å ta bevisste valg i utviklingsprosesser av produkter. Dette skulle gjøre elevene i stand til å forholde seg nysgjerrig, skapende og kritisk til teknologi i hverdagen. Hva er igjen av dette i undervisnings materiellet vi undersøker?

I eksemplene "Mekanisk leke" og "Elektronisk jakkmerke" ledes elevene gjennom en trinnvis prosess der de gjentar etablerte løsningsforslag, men oppfordres til å lage sin egen variant av produktet. Slik disse oppgavene er utformet legger de lite til rette for at elevene skal ta bevisste valg, derimot skal de reprodusere andres valg. Hvordan ville de samme oppgavene forløpt dersom elevene hadde fătt langt åpnere oppdrag: Lag en mekanisk leke som kan trekkes på hjul, der bevegelse overføres fra hjulene til en figur? eller Lag en gjenstand med tre lysdioder hvor du finner et egent bruksområde? I begge tilfeller skaper de et produkt, 
men med et åpnere oppdrag må de også skape løsningen og forstå hvorfor og hvordan noe virker. Vår antagelse er at et forløp der elevene selv får lov å lure, må stille spørsmål og søke svar, vil føre til større forståelse for bevegelsesmekanikk og sammenhengen mellom form og funksjon. I Norsk Form sitt eksempel er det rom for det skapende og nys gjerrige: elevene skal formulere et spørsmål, lure på noe - være nysgjerrige - gjennom en problemstilling som de skal tilnærme seg gjennom designprosessen. Denne prosessen kan stimulere elevene til å forstå hvordan produkter blir til gjennom bevisste valg i gitte sammenhenger, noe som peker mot den didaktiske begrunnelsen fra Teknologirådet. En forutsetning for å nå dette er å gjøre T\&D til et reelt flerfaglig emne, der en anerkjenner partnerskapet mellom design og teknologi ved produktutvikling. Oppskriftene bør da forlates til fordel for at elevene selv konstruerer løsningene gjennom bruk og utvikling av sine kunnskaper. Det forutsetter undervisningsopplegg der elevene må finne og plukke problemene fra hverandre, analysere bruk og tilgjengelig teknologi, eksperimentere frem ulike løsninger gjennom å bruke designprosessen som verkt $\varnothing y$, matematiske redskaper, naturvitenskapelige prinsipper og sin visuelle kompetanse. Vi går tilbake til artikkelens innledende sitat. Ved hjelp av små justeringer kan de aktuelle undervisningsopplegg ha potensial til å underst $\varnothing$ tte skapende og nysgjerrige holdninger til $T \& D$, men hva med det kritiske?

I den senmoderne marked søkonomien blir estetisering et virkemiddel for å vinne nye forbrukere for å opprettholde det kapitalistiske kretsløpets trang til overskudd, en tilnærming som har fått benevnelsen markedsestetikken (Persson 2004:125). I følge Persson (ibid:141) knytter markedsestetikken symbioser mellom økonomi, teknologi og estetikk. Disse symbiosene bidrar til å skape nye, funksjonelle, brukervennlige og vakre gjenstander for brukeren med basis i skapte og reelle behov. Denne estetikken bidrar i så måte også til å skape markedet for konsumpsjonen av produktene (Sparke $2006: 1-2)$.

Gjennom produktutviklingsprosesser kan elever rett nok få erfaring med hvordan teknologiske og designede systemer og gjenstander blir til, av folk som tar bevisste valg i gitte sammenhenger. Noe som i følge Teknologirådet (2004) kan føre til at elevene kan forholde seg kritiske til teknologi. Men hva kan de stille seg kritiske til? Om gjenstanden fungerer teknisk eller funksjonelt? Om den passer min målgruppe? Om de synes den har en god komposisjon? Dersom de kritiske perspektivene ender her, bidrar dette kanskje ikke til annet enn å skolere den gode produsent, og ytterligere forsterke den gode konsument. De fire tilnærmingene til undervisning i T\&D som vi har skissert, kan derfor forstås i et dobbelt perspektiv: Både som et potensial for læring av kunnskaper og ferdigheter i naturfag, matematikk, design og teknologi, men samtidig som et sted hvor markedsestetikken blir stående uproblematisert. For hva fører markedsestetikken med seg av miljømessige, samfunnsmessige, sosiale og mentale utfordringer? Er disse ønskelige? Hvorfor skal ikke elevene gjøres oppmerksomme på slike perspektiver gjennom T\&D? Må eleven innfinne seg med at han er en forbruker og produsent i et samfunn han ikke kan påvirke?

De fire tilnærmingene til undervisning i T\&D og Bungums firedelte liste over tilnærminger til teknologi er dermed mangelfull; det kritiske sett i forhold til den samfunnsmessige og kulturelle forankringen T\&D synes fraværende i alle. Fraværet av det kritiske gir grunn til å stille spørsmål ved hvilken motivasjon som ligger bak vinklingene på T\&D i det aktuelle undervisningsmateriell: Oppfostring av nye generasjoner produsenter og konsumenter som kan være beredt til å bære det marked sliberale samfunnet videre etter oljeeventyret?

I dette perspektivet kan Kunnskapsløftets formulering av T\&D som flerfaglig emne mellom kunst og håndverk, matematikk og naturfag synes smal. Betydningen av å inkludere fagområder som samfunnsfag, religion og livssyn synes prekær. Men, som Bungum (2006) påpeker, kan en tverrfaglig tilnærming for å sette etikk og kritiske perspektiver på agendaen bli regnet som overflødig og lite meningsfylte for eleven, da de vil komme på siden av det emneområdet fremstiller som vesentlig kunnskap. Dermed kan det synes mer presserende for 
T\&D at disse kritiske perspektivene vokser innenfra emneområdet. Kan produktutvikling både ivareta brukerens perspektiver; skape teknologiske, funksjonelle, vakre artefakter, og ivareta kritiske tilnærminger til T\&D?

Men før dette spørsmålet kan undersøkes, er det en annen utfordring emneområdet står overfor. Hva skal vi med T\&D på timeplanen? I undervisningsmateriellet som vi har analysert finner vi ulike begrunnelser for hvorfor T\&D skal ha en plass i norsk skole: Emneområdet kan forstås som et middel til å styrke realfagene, gjennom praktisk læring av naturvitenskapelige prinsipper. Eller som et mål i seg selv, hvor produktutvikling blir omdreiningspunkt for å forstå den gjensidige avhengigheten og partnerskapet mellom teknologi, naturfag og design. Men; T\&Ds rolle i disse perspektivene blir speilets - å gjenspeile det som samfunnet stiller av krav til kompetanse og arbeidskraft, det Persson (2004:132) kaller en ukritisk tilpasning til markedet. Vi har også sett at kritiske tilnærminger glimrer med sitt fravær i undervisningsmateriellet, til tross for Teknologirådets visjon. Kanskje dette ikke er noe problem? Dette handler om hvilke didaktiske begrunnelser vi ønsker for T\&D i norsk skole; hvorfor elever skal ha T\&D på timeplanen. Vår analyse viser at det er behov for mer didaktisk refleksjon rundt emneområdets oppgave og innhold i skoleverket. Vi etterlyser en videre didaktisk diskusjon på tvers av kunnskapsområdene.

\section{Anna Auste stad}

Dr. stipendiat

Avdeling for estetiske fag Høgskolen i Oslo

Email adresse: Anna.Austestad@est.hio.no

\section{Eva Lutnæs}

Dr. stipendiat

Avdeling for estetiske fag Høgskolen i Oslo

Email adresse: Eva.Lutnas@est.hio.no

\section{Referanser}

Briså, S., Ingebrigtsen, R. \& Jørgensen, E. C. (2006). Teknologi-og designboka. Oslo: Damm.

Briså, S. \& Hansen, P. K. (2004, 26. januar). Teknologi som nytt fag i skolen. Aftenposten. Lastet ned 11. mars $2008 \mathrm{fra} \mathrm{http://www.aftenposten.no/meninger/kronikker/article} \mathrm{716836.ece}$

Bungum, B. (2006). Teknologi og design i nye læreplaner i Norge: Hvilken vinkling har fag o mrådet fått i naturfagsplanen? NorDiNa (4), 28-39.

Kunnskapsdepartementet (2006). Lareplanverket for Kunnskapslфftet. Midlertidig utg. juni 2006. Oslo: Utdanningsdirektoratet.

NITO (2008). Teknologi og design i norsk grunnskole. Lastet ned 26. mars 2008 fra http://www.nito.no/kurs-ogkarrie re/Utdanning/Teknologi-og-design/

Norsk Form (2005). Teknologi og design. Lastet ned 11. mars 2008 fra http://www.norskform.no/default.asp?V_ITEM_ID=2005

Paulsen, V. (2008). Elektronisk jakkemerke. Lastet ned 11.mars 2008 fra http://www.naturfag.no/ ungdom/fors ok/vis.html?tid=337152

Perss on, M. (2004). Marknadsestetiken. I L. Aulin-Gråhamn, M. Pers son \& J. Thavenius.(Red.) Skolan och den radikala estetiken. Lund: Studentlitteratur.

Renatesenteret (2005). Teknologi og design. Hefte for barneskolen. Oslo: Renatesenteret. Lastet ned fra http://www.renatesenteret.no/Heftet complete web.pdf

Simons, H. (1969). The Sciences of the Artificial. Cambridge MA: MIT Press.

Sparke, P. (2006). Introduction. Twentieth-century design and culture revisited. I Sparke, P. An introduction to design and culture. 1900 to the present. London: Routledge.

Teknologirådet (2004). Fra rådet til tinget. Teknologi i skolen. Nyhetsbrev nr. 8. mai 2004. Lastet ned 11. mars $2008 \mathrm{fra} \mathrm{http://www.teknologiradet.no/dm} \mathrm{documents/TEK \%} \mathrm{20Nyhetsbrev \% 20nr \% 208} \mathrm{qyceC.pdf}$

Utdannings - og forskningsdepartementet (2004). Kultur for laring. St. meld. nr. 30 (2003-2004). Oslo: UFD.

Utdannings-og forskningsdepartementet (2002). Realfag, naturligvis - Strategi for styrking av realfagene 2002 2007. Publisert 13. november 2002. Redigert versjon januar 2005. Lastet ned 12. mars 2008 fra http://www.regjeringen.no/upload/kilde/ufd/rap/2002/0013/ddd/pdfv/235427-realfag.pdf

Utdannings - og forskningsdepartementet. (2003). I første rekke. Forsterket kvalitet i en grunnopplacing for alle. (NOU 2003: 16). Oslo: UFD. 
Øyan, A. S. (2004). Design - mellom kunst og teknologi. I: L.M. Nielsen (Red.) DesignDialog - designforskning $i$ et demokratisk perspektiv. Oslo: Høgskolen i Oslo.

\section{Bildeliste}

Figur 1: Briså, S., Ingebrigtsen, R. \& Jørgensen, E. C. (2006). Teknologi-og designboka. Oslo: Damm.

Figur 2: Naturfag.no (2008) Lastet ned 22. august 2008 fra

http://www.naturfag.no/ barn/nyhet/vis.html?tid=888386.

Figur 3: Norsk Form (2005) Lastet ned 22. august 2008 fra www.norskform.no/default.asp?FILE=ite ms/2005/184/Design\%20av\%20 mobiltelefonhol der $\% 20$ Tros vik mini.pps

\footnotetext{
${ }^{1}$ For en mer utfy llende beskrivelse av fremveksten av Teknologi og design som flerfaglig emne i grunnskolen, se Berit Bungum (2006) Teknologi og design i nye laereplaner i Norge: Hvilken vinkling har fagområdet fått i na turfagsplanen? ${ }^{2}$ Renatesenteret er Nasjonalt senter for rekruttering til realfag.

${ }^{3}$ Bungum (2006) foretar en analyse av teknologi og designs påvirkning på læreplanen i Naturfag. Hun konkluderer med at prosessen frem mot Kunnskapslфftet sliper nytenkende formuleringer mot "tradisjonens rullesteiner" i retning av en mer tradisjonell læreplan for Naturfag.
} 